JOURNAL OF SECURITY AND SUSTAINABILITY ISSUES

ISSN 2029-7017 print/ISSN 2029-7025 online

2021 Volume 11

https://doi.org/10.47459/jssi.2021.11.15

\title{
EDUCATION OF PRISON GUARD OFFICERS IN THE SECURITY SYSTEM OF THE SECOND POLISH REPUBLIC (1918-1939)
}

\author{
Bartosz Kulan \\ Academy of Justice, 50 Wiśniowa Street, 02-520 Warsaw, Poland \\ E-mail: bartosz.kulan@swws.edu.pl
}

Received 23 October 2020; accepted 13 April 2021; published 30 June 2021

\begin{abstract}
This paper outlines various issues concerning education of Prison Guard officers in the security system of the Second Polish Republic. The subsequent parts of the paper highlight a short outline of the history of the Polish prison system in the years 1918-1939, the functioning of the Prison Guard in the Second Polish Republic, as well as training methods employed by the organisation. The issues highlighted in the paper address key aspects concerning Prison Guard education. The first part of the article offers a broader outline of the issue at hand, showcasing some of the characteristic elements of the Polish penitentiary system in the years 1918-1939, in particular in the 1920s, which were particularly difficult for the reborn Polish state, as the Second Polish Republic had to face various challenges concerning its external and internal security. This, of course, had its impact on the condition of the Polish prison system, as the newlyestablished penitentiary system faced various problems and issues. The terrible shape of the buildings, poorly trained staff and dire conditions faced by prisoners serving their sentences led the state authorities to undertake the painstaking task of creating an efficient penitentiary system from scratch. From the point of view of the entire interwar period, this task can be deemed successful, as the state of prisons in the 1920s was significantly worse compared to the 1930s. The training and education of Prison Guard officers was an integral and inseparable part of the development of the Polish penitentiary system. This paper outlines the educational process and subsequent forms of schools educating and training future prison guards. What is more, it also highlights their main objectives, the subjects taught and the figures of lecturers responsible for teaching individual subjects, concluded with a summary.
\end{abstract}

Keywords: prison guards; prison system; internal security; history of prison system; prison system in Poland 1918-1939; education of prison guards

Reference to this paper should be made as follows: Kułan, B. 2021. Education of prison guard officers in the security system of the second Polish Republic (1918-1939). Journal of Security and Sustainability Issues, 11, 187-194. https://doi.org/10.47459/jssi.2021.11.15

Additional disciplines: law; educology; history.

\section{Introduction}

The paper outlines a variety of issues pertaining to the education and training of Prison Guard officers in the Second Polish Republic (1918-1939) and their role in the security system in the interwar period. In the aftermath of the events of 1918, the reborn Poland faced a major challenge of establishing and organising the entire state system from scratch, like Lithuania did, as well as to regulate all internal and external matters. In the case of the former, this primarily concerned ensuring the safety of citizens by taking care of prison security and by establishing, and then training, the prison guard force. By all accounts, this was one of the more important, though often forgotten, aspects of homeland security (cf. Bedyński, 1989, p. 7, Migdał, 2011, pp. 266-303, Migdał 2012, pp. 633-688).

After regaining independence, Poland had to face various challenges, one of which was the increase in crime rates. The reasons for this state of affairs were manifold; however, some of the most crucial among them included widespread access to firearms, the high unemployment rate, and the trauma of World War I - in particular the war-time violence, disrespect for life and looting, which pushed people to engage in crime. Because of that, 
the authorities of the reborn state had to take care of the safety of citizens not only by organising and funding police operations aimed at detecting and apprehending criminals, but also by supporting an important branch of the justice system - prisons, which was to be staffed by Prison Guard officers, who were to play a key role in the latter area by supervising prisoners and work on their readaptation. This, in turn, led to the need to establish schools that would provide the state with a staff of trained officers (Pawlak, 1994, pp. 34-36, Bedyński, 2009, pp. 38-39).

The Prison Guard officer training system in the Second Polish Republic was based on the original solutions developed by the most prominent representatives of Polish penitentiary thought, including, but not limited to Zygmunt Bugajski, Emil Stanisław Rappaport and Leon Radzinowicz. The former in particular has made a very important contribution to the system prison staff education and training. The schools designed for Prison Guard officers were based mainly on his ideas and they operated right until the outbreak of World War II. It is also worth noting that thanks to this innovative approach, a wide range of subjects and the proper selection of the course contents, they served their role well and led to raising the skills and qualifications of prison staff year by year (cf. Kułan, 2017, pp. 96-112).

The subsequent parts of this paper focus on presenting the general characteristics of the Polish prison system in 1918-1939, outlining the circumstances and the standing of its officers, as well as describing the education of prison staff in the Second Polish Republic, concluded with a summary. By principle, the article is organised chronologically and with focus on particular issues, which is why the author decided to first describe the broader context of specific events in order to later present the key issue mentioned in the title. Focusing on the main theses of this article, they revolve around a number of elements, the first of which is an attempt to showcase the role of prison officers in ensuring internal security in the Second Polish Republic. It seems that within the scope of this role, one of the most important aspects was the proper selection of penitentiary staff, followed by proper education and training. Claiming that without proper education of officers it would be difficult to properly ensure the security of prisons and readaptation of convicts might sound like a cliché, raising new questions and research theses pertaining to the description of the course and effectiveness of the prison officers training process in the Second Polish Republic and giving a start to an attempt at answering the question of its contribution to the improvement of internal security in the reborn Polish state.

Due to its limited size, this paper showcases only some of the most important aspects of the issue at hand. The choice of subject and historical period was dictated by the author's research interests and his previous publications on the prison system in the Second Polish Republic.

\section{Polish prison system in the years 1918-1939 - general characteristics}

After regaining independence in 1918, the Polish authorities had to ensure the country's independent existence as a state, along with its relative external and internal security. The first of these elements concerned stable borders and regulating the country's international position through participation in peace conferences and diplomatic activities - of these elements, the former was particularly crucial, as the reborn Poland had to ensure the stability of its own borders, which often led to conflicts with its neighbours. The western border was constantly threatened by Germany, the southern - by Czechoslovakia, and on the east, the new-born state neighboured Soviet Russia. The young state did not have the strength or resources to protect the Poles living in those areas; that is why the Polish populace living in these areas were quite adept at organising uprisings and military organisations, which enabled incorporating these into the Polish state. Among the most important border fights of that period there were the Greater Poland Uprising, three Silesian Uprisings and territorial squabbles with Ukrainians and Lithuanians. The Soviet Union was one of the gravest threats to the nascent Polish state, resulting in a Polish-Bolshevik War, which raged on from 1918 to 1921 with varying intensity (Davies, 1999, pp. 190-228). Only after winning the Battle of Warsaw and signing the Treaty of Riga did Poland's eastern border stabilise (cf. M. Fic, J. Lusek, J. Załęczny (eds.), p. 243). The final act of the struggle for the borders of the Second Polish Republic was the occupation of Vilnius by the Polish armed forces in 1921, which led the diplomatic relations with Lithuania to be broken off for many years. This shows that in spite of the fact that World War I 
ended in 1918, the international situation of the Second Polish Republic did not stabilise until three years later (ibidem, pp. 57-72).

In addition to the international situation, which threatened the external security of the nascent state, Poland also struggled with internal problems, the most important of which was the need to re-establish all state institutions from scratch after nearly 123 years of partitions. The state authorities dealt with this problem rather quickly and established new institutions to ensure its proper functioning, including a parliament, a government and relevant ministries. Given these circumstances, one of the key elements was establishment of the justice system and the prison system as one of its key foundations. The prison supervision system was based on the model lifted from the Russian partition, in which prisons were beholden to a central authority - the Ministry of Justice. ${ }^{1}$ The state authorities managed to take over prisons from the partitioning powers rather quickly - the last prisons were taken over in 1922 as a result of the incorporation of Upper Silesia to Poland (Pawlak, 1994, pp. 7-9).

Moving on to a brief characterization of the Polish prison system in the early 1920 s, one needs to note that the situation was dire, with most prisons destroyed and looted. Even during World War I, the retreating Russian and later German armies engaged in widespread looting, including in prisons, resulting in significant damage, in particular to prison industrial plants, which - not unlike civilian factories - were dismantled and then taken deep into Russia or later into Germany. By the end of World War I, some prisons remained abandoned. Without any care, the buildings deteriorated and became an easy target for the local populace, who - pushed to the brink by poverty - stole any things of value. One of the examples of this phenomenon may be the Święty Krzyż prison, where residents of the surrounding villages stole everything - including ceilings and floorboards (Kułan, 2013, p. 48). Another issue that pointed to grave problems with the prison system in the Second Polish Republic in the early 1920s was the high mortality rate among inmates, reaching even about $30 \%$ in some prisons. Due to the lack of investments in the prison system, convicts came down with various diseases, including tuberculosis, scurvy and various digestive ailments, which were particularly rampant. Prisons were poorly heated and lacked the most basic necessities. Over the years this situation improved to stabilise by 1927 (Przeniosło, 2000, p. 219).

In the late $1920 \mathrm{~s}$, the state authorities made a decision to reform the penitentiary system in response to improving economic situation in Poland and the country's position on the international arena. The first legal act regulating these issues entered into force in 1919, but it was hardly extensive and regulated only basic issues, with many sections stating that more precise regulations would not come until a later date. Although this act was short and contained only 12 articles, it specified, among other things, that the prisons would introduce the main principles of the progressive system based on work, study and spiritual care for the convicts (cf. Dziennik Praw Państwa Polskiego [Journal of Laws of the Polish State] of 1919, no. 15, item 202) It was not until 9 years later - in 1928 - that the first comprehensive regulation of the Polish prison system was introduced. The 1928 decree of the President of the Republic of Poland regulated virtually every aspect of the Polish penitentiary system, while introducing prison work and education for the inmates on a larger scale. This legal act comprised 72 articles and remained into force until the outbreak of World War II. With time, the conditions and situation in the prisons also improved, with more and more humane solutions taking hold. Many inmates received education or learned trades at local plants and workplaces. Prisoners were also employed in the summer months doing field work. Physical education and exercise were also gradually introduced in the prisons (cf. Urban, 2016, pp. 11-27; Kułan, 2020, pp. 54-75). All of these activities made imprisonment less severe and more humane; however, the outbreak of World War II put a swift end to these achievements. The above-mentioned legal acts were the most important documents regulating the penitentiary system in the Second Polish Republic. The final legislation concerning the Polish prison system came into force in August 1939 and, due to the outbreak of World War II, was never actually introduced in Poland (cf. Dz. U. 1939, no. 68, item 457).

1 Unlike the Prussian partition, where prisons were supervised by local courts. 


\section{Prison Guard in the Second Polish Republic}

The situation of the Prison Guard in the Second Republic was very similar to the conditions in which the interwar penitentiary system was created. As noted above, the prison system was underfunded and could not afford everyday necessities, and the situation of the Prison Guard officers was no different, as they faced the shortage of basic items such as shoes and uniforms (Matysiak, 2006, p. 20). The prison staff could also be hardly described as the best - throughout the first half of the 1920s, the Prison Guard was mostly made up of ex-military men who were unable to serve at the front for various reasons, and their only task was to supervise the inmates and prevent prison breaks. This was also reflected in the requirements for officers. In line with the 1919 legislation, they were not particularly high - Candidates for prison guards had to complete a six-month internship, during which they were familiarised with the prison and its operations. Other than that, they were supposed to know the so-called military discipline, which clearly shows that the requirements were not too extensive. As a result, in many cases prisons were staffed by people, who only met the basic criteria required in 1919 . This was particularly worrisome from the point of view of internal security, as poorly trained officers could not ensure proper performance of their duties (cf. Migdał, 2011, pp. 266-303).

It was only in subsequent years that the requirements for officers were gradually raised. In 1925, a regulation was introduced that the candidates for prison guards had to be at least 165 centimetres tall and younger than 35 . What is more, the prospective officer had to pass a Polish reading and writing exam and should be able to solve four arithmetic operations (ibidem, p. 274). The situation changed even further in 1932, when the presidential decree normalising the operations and functioning of the Prison Guard Corps entered into force, setting out the rights and responsibilities of prison guards and significantly raising the requirements for joining their ranks. According to the provisions of the decree, the prospective officer should have Polish citizenship, be between 21 and 35 years of age, have a good command of the Polish language, have graduated from a primary school, have an unblemished record and be physically and mentally fit to work in the prison service (Dz. U. [Journal of Laws] of 1932, no. 74, item 667, art. 14-15).

Subsequent legal acts of the Second Polish Republic imposed additional requirements on Prison Guard officers, concerning mainly the treatment of inmates and rehabilitation work (cf. Dz. U. [Journal of Laws] of 1928, no. 64, item 591). The Prison Regulations of 1931 provided that officers were to influence the change of the inmate by undertaking measures aimed at fostering that change. The 1931 legislation was viewed very positively by contemporaneous experts. Representatives of the academic community of the Second Polish Republic unanimously claimed that the regulations changed the work with convicts and duties of guards, as the Prison Guard officers ceased to be merely supervisors who prevented escapes and guarded the prisoners, and became responsible for the prisoners and their successful return to society. ${ }^{2}$

The main objective of the pre-war Prison Guard was to ensure order and safety in prisons and to conduct rehabilitation activities. Until 1932, Prison Guard officers were treated as civilian employees with the right to bear arms, and in 1932 the Prison Guard was transformed into an armed formation with lower and higher-ranking officers. They were bound by the rules of military discipline, the formation had proper service ranks and the duty to obey orders. As such, the officers underwent training that was based on military regulations, albeit not as demanding as in the armed forces. Prison Guard officers did not participate in manoeuvres and did not have as many military drills as the regular army; however, in the case of war, officers who were not subject to mobilisation were supposed to ensure security and safety in prisons. Their tasks included evacuating prisoners and securing transports. The war strategies did not envisage using the Prison Guard in military operations, mainly due to the fact that the formation had nearly no combat value, mainly due to their modest equipment - solely small arms and bolt-action rifles. In spite of the relatively low combat value of the Prison Guard, the events of World War II demonstrated that many officers followed their duty, even if they had to pay for this with their own lives and health (Kułan, 2017, pp. 77-95).

\footnotetext{
2 This was pointed out by many scholars, chief of whom was Z. Bugajski - one of the most outstanding representatives of Polish penitentiary thought. (cf. Przegląd Więziennictwa Polskiego, 1931 no. 11 p. 20).
} 
After the German attack on Poland in September 1939, the Prison Guard was responsible for the evacuation of prisoners to eastern Poland. In spite of the chaos and constant Luftwaffe air raids, the inmates were successfully evacuated to prisons in Warsaw and across eastern Poland. After the defeat and during the occupation by Soviet and German armies, the cast majority of officers went into hiding for fear of retaliation, many of them actively joined clandestine organisations, and many fell victim to brutal repressions - Many officers, in particular those living in western parts of Poland, were sent to the Auschwitz concentration camp (cf. Czyżowicz, Orlikowski, 2018, pp. 93-107). The officers of the eastern territories met a similar fate. Lower-ranking officers were deported with their families to Siberia, while officers were sent to POW camps in the USSR, and the majority was murdered in Katyn and Tver (cf. Bedyński, 2007, pp. 56-57).

\section{Prison Guard officer training in the Second Polish Republic}

In the Second Polish Republic, Prison Guard officers were subject to training, like all other uniformed formations. Admittedly, the system of education of the Prison Guard saw many changes throughout the period of 1918-1939; however, it always followed the rules of progressivism, which was the foundation of the prison system of the Second Polish Republic. The training of Prison Guard officers was developed by Z. Bugajski. In 1923, the Ministry of Justice made the decision to establish a Schooling Commission tasked with developing schools for officers. The plan to establish the school, select the teaching staff and develop the curriculum was entrusted to Z. Bugajski. who believed that the key element of education was to introduce a broad range of subjects that extended far beyond learning prison regulations by heart, which is what led him to inviting prominent representatives of sciences such as criminology, psychiatry, psychology and dactyloscopy to collaborate with the prison school (Kułan, 2017, p. 105). Bugajski also saw the need to establish the so-called training school, namely a large prison, where on-the-job training could be carried out for the prospective officers. What is worth noting, Bugajski was an advocate of intramural training of prison officers - as a result of his decision, the Prison Guard School was established in Warsaw, which was supposed to facilitate access to academic staff working at the University of Warsaw and the Free Polish University, as well as give the Ministry of Justice an opportunity to see the results of his education. Taking into account the fact that the Second Polish Republic was a vast country with a poorly developed railway network, the basic training of newly recruited officers took place in prisons, where they worked. At a later time, selected guards were summoned to Warsaw for training. Not all the ideas proposed by Bugajski came to fruition; however, the Ministry of Justice had a hard-working and proficient organiser, who was able to establish officer training schools and taught officers personally for many years (cf. Ibidem, pp. 96-111).

In the Second Polish Republic, the first institution tasked with teaching and training Prison Guard officers was called the Central School of the Ministry of Justice. It was launched in 1923 and operated until 1932. The educational course for the prison guards was 4 months long, and throughout its duration, the guards lived in barracks and underwent medical examinations. According to the training schedule, a week's training included 30 hours of lectures and 12 hours of practical workshops. The key subjects taught at the school included theory and practice of the prison system, the study of prison regulations, criminal etiology and psychology, elements of criminal law, state law, fiscal and administrative law, clerical regulations, dactyloscopy, merceology, first aid, hygiene and fire regulations (Przeglad Więziennictwa Polskiego, 1927, p. 15). In addition to the above subjects, general education classes were also offered at the school - Polish history, geography and Polish language courses. The school also paid great importance to physical education (Kułan, 2020, p. 72). The officers were taught Eastern martial arts, and their education focused primarily on incapacitating an opponent. One student from 1927 remembered them as "Japanese moves and embraces" (Przegląd Więziennictwa Polskiego, 1927, p. 15). In addition to specific subjects, the school also put some focus on the so-called patriotic education. Due to the fact that many of the students came from different regions of Poland and in many cases they visited Warsaw for the first time in their lives, the school tried to familiarise them with the history of the country through trips and visits to the most important monuments in the capital. One of the officers attending the course recalled: "I benefited greatly from the excursions, especially from my visit to the Royal Castle, where I saw many beautiful mementos concerning my nation" (Przeglad Więziennictwa Polskiego, 1927, p. 27). Patriotic education also included organisation of official celebrations of anniversaries and national holidays, such as ceremonies commemorating the centenary of the outbreak of the November Uprising or the anniversary of the signing of the 3rd of May Constitution. The celebrations were usually 
held within the walls of the Central School, and representatives of the Ministry of Justice were invited to take part. Depending on the date of the course, its participants also took part in state ceremonies in Piłsudskiego Square in Warsaw - their presence and active participation was noted several times during ceremonial parades in front of the most important state figures (Przegląd Więziennictwa Polskiego, 1932, p. 13).

The Central School of the Ministry of Justice put great emphasis on the high quality of the provided education and courses. However, this led to some problems, as the very ambitious attitude of some lecturers was sometimes inadequate to the level of knowledge presented by individual officers, as a result of which people in charge of the school at the Ministry of Justice decided to revise the curriculum. In the aftermath of these changes, after arriving in Warsaw, the students attended general classes, learning Polish, history, mathematics and geography for several weeks. The preliminary education concluded with an exam, and only then did the students move on to the more difficult subjects mentioned above. In order to ensure the effectiveness of the training, the Ministry of Justice has also prepared guidelines that read: "The students cannot be overloaded right from the start. In order to avoid this (...) only 2-3 hours should be devoted to lectures twice a week for each group of prison guards" (Przeglad Więziennictwa Polskiego, 1927, p. 3). In spite of that, there were cases where students were not able to handle the excessive workload required by the lecturers, and on several occasions they had to be sent home due to insufficient knowledge or being physically unfit for duty. In order to avoid such situations, prison wardens were asked to choose officers, who - according to them - would be able to finish the school. ${ }^{3}$

In addition to selecting the right students, another key element was the introduction of the right curricula. The content of the subjects taught at the school was developed by the instructors, who were also responsible for conducting the exams. Z. Bugajski, who established the Central School on behalf of the Ministry of Justice, invited prominent scholars and researchers to work at the School, including some prominent figures of the time university professors Janusz Jamont (lawyer), Kazimierz Stołychwo (lawyer), Witold Łuniewski (psychiatrist), Leon Radzinowicz (lawyer - criminologist) and Emil Stanisław Rappaport (lawyer). In addition to the staff made up of university professors, classes were also taught by employees of the Ministry of Justice, as well as practitioners, Prison Guard officers and police officers. The staff was also responsible for developing textbooks for the students, which was a particularly important issue due to the fact that following 123 years of partitions, textbooks and scripts in Polish were virtually non-existent. Bugajski was particularly active in this field, as he wrote more than $50 \%$ of all textbooks published by the school (cf. Kułan, 2017, p. 106).

The courses at the Central School were somewhat formulaic - the ceremonies marking the start of the course began with an official service in the chapel of the Pawiak prison, attended by the representatives of the Ministry of Justice, lecturers and students of the course. Later, after the national anthem was played in the main auditorium of the school, an official welcome ceremony was held, and the participants were welcomed by the Director of the Criminal Department of the Ministry of Justice, followed by a lecture by one of the professors of the Central School. For example, during the opening of the 21 st course in 1931, the inaugural lecture on the new prison regulations was given by Z. Bugajski. The official part was followed by an official dinner for course participants, lecturers and representatives of the Ministry of Justice (Przeglad Więziennictwa Polskiego, 1931, pp. 13-14). The course endings also followed a similar formula - starting with a speech by one of the Ministry of Justice delegates, followed by the diploma ceremony for course graduates. In later years, officers who achieved the best results were offered cash prizes and - in some cases - silver watches (Przeglad Więziennictwa Polskiego, 1929, pp. 10-11). The course graduates were also encouraged to pass on the knowledge they had acquired to younger colleagues and staff in their local prisons (Przeglad Więziennictwa Polskiego, 1928, p. 9).

The first institution training prison guard officers in Second Polish Republic managed to train the vast majority of the Polish prison staff in 1923-1932. In 1932, with the entry of the Presidential Decree on the creation of the Prison Guard Corps entered into force, the decision was made to change the name of the Central School of the Ministry of Justice, which was to be accompanied by far-reaching changes - as a result, the single facility was replaced with two schools, one for the lower-ranking, and the other for the higher-ranking Prison Guard

3 It was also pointed out that the selection of ill-prepared officers and sending them to Warsaw generated unnecessary costs connected with rail travel. See also: Przegląd Więziennictwa Polskiego, 1929, no. 3, p. 7. 
officers. The main focus of the curriculum was to expand the content of some subjects and tailor it to a specific group of officers, and the list of subjects was expanded to include criminal anthropology, criminal policy, criminal sociology, psychopathology, and prison education (cf. Kułan, 2017, pp. 108-109). According to Z. Bugajski, broadening the curriculum was supposed to expand the student's knowledge of the latest developments in criminology and penitentiary science. The school for higher-ranking officers was established in the Pawiak Prison buildings, and the new institution for lower-ranking officers was moved to the Arsenal building on Długa Street (Bugajski, 1933, p. 7); however, the two new institutions training prison guards did not last very long, as less than three years after their establishment, a new legal act came into force, regulating the organisation of the Prison Guard training, which merged the two schools into a single institution back again. This gave rise to the Prison Guard School, which operated until 1939 - with new curriculum and courses for lower- and higherranking officers, which were classified respectively as: higher, educational-penitentiary and security courses (ibidem, pp. 83-89). These courses were only two months long, mainly due to the fact that the school was underfunded as a result of the ongoing economic crisis. Cash and in-kind awards for top graduates of the course were also abolished for the time being; instead, seeing the changing international situation and the threat of war, the students themselves made small donations for improving the country's defence and to purchase equipment for the armed forces (Przeglad Więziennictwa Polskiego, 1936, p. 11).

\section{Conclusions}

The Prison Guard training system, which was in force in the Second Polish Republic was based on original solutions developed by the representatives of the Polish interwar penitentiary thought. It was largely created and developed by Z. Bugajski, who introduced and implemented an education system based on the principles of progressivism, in line with his own beliefs. In spite of difficulties, which were manifold, Prison Guard officers in the Second Polish Republic were trained and prepared for difficult service in prisons, learning an astounding set of subjects - many Western European countries did not offer such an extensive penitentiary studies curriculum for prison guards at the time. It might seem that the Prison Guard schools have served their purpose, namely enabling the training of the majority of prison guards working in the penal institutions of the Second Polish Republic. Thanks to the extended curriculum, the students had access to knowledge of the latest achievements of penitentiary studies, while learning patriotic and civic attitudes. Unfortunately, all the achievements made in the interwar period were ruined by the outbreak of World War II. Many of the officers also suffered a tragic fate. In general terms, the Prison Guard as a formation and the Prison Guard officers constituted a very important element of the so-called internal security system in the Second Polish Republic. In spite of the fact that the formation did not have a great military value, one would be hard-pressed to imagine the state security system without well-trained and dedicated Prison Guard officers.

\section{References}

Bedyński K. (1989). "Szkolenie zawodowe Straży Więziennej w latach 1918-1939 (Professional training for the Prison Guard in 1918-1939)" Gazeta Penitencjarna, no. 9.

Bedyński K. (2007). “Więziennicy zamordowani w Katyniu (Prisoners murdered in Katyn),” Przegląd Więziennictwa Polskiego, no. 56-57.

Bedyński K. (2009). “Personel się szkoli (The staff is training),” Forum Penitencjarne, no. 7.

Bugajski Z. (1933). “Organizacja wyszkolenia kryminologiczno-penitencjarnego w Polsce (Organization of criminology and penitentiary training in Poland), "Przegląd Więziennictwa Polskiego, no. 2.

Czyżowicz A., Orlikowski W., (2018). Straż Więzienna - Stużba Więzienna (Prison Guard - Prison Service, KiD), KiD, Warsaw.

Davies N. (1999). Biaty Orzet - Czerwona Gwiazda (White Eagle - Red Star), Warsaw. Znak.

Dz. U. [Journal of Laws] of 1928, no. 64, item 591.

Dz. U. [Journal of Laws] of 1932, no. 74, item 667.

Dz. U. [Journal of Laws] of 1939, no. 68, item 457. 
Dziennik Praw Państwa Polskiego [Journal of Laws of the Polish State] of 1919, no. 15, item 202

Fic M., Lusek J., Załęczny J., (2020) Granice wolności-granice Niepodległej 1918-1922 (Limits of freedom - borders of the Independent Poland 1918-1922) Katowice. University of Silesia.

Kułan B. (2020). "Poglądy Zygmunta Bugajskiego (1887-1940) na wychowanie fizyczne więźniów oraz ich praktyczna realizacja w systemie penitencjarnym II Rzeczpospolitej (Views of Zygmunt Bugajski (1887-1940) on the physical education of prisoners and their practical implementation in the penitentiary system of the Second Polish Republic)," Kwartalnik Pedagogiczny, no. 2.

Kułan B. (2013). Bunt w więzieniu na Św. Krzyżu w dniu 20 września 1925 r. (Mutiny in the prison on St. Krzyż on September 20, 1925), Toruń, Europejskie Centrum Edukacyjne.

Kułan B. (2017). Nieznana ofiara Katynia. Zygmunt Bugajski (1887-1940) prawnik i penitencjarysta (Unknown victim of Katyn. Zygmunt Bugajski (1887-1940) lawyer and penitentiary). Krakow, Petrus.

Matysiak W. (2006). Historia Więzienia na Świętym Krzyżu (History of the prison on the Holy Cross), Kielce, Studenckie Koło Przewodników Świętokrzyskich.

Migdał J. (2011). Polski system penitencjarny w latach 1928-1939 (Polish penitentiary system in the years 1928-1939) (. Gdańsk, Arche.

Migdał J. (2012). Polski system penitencjarny w latach 1918-1928 (Polish penitentiary system in the years 1918-1928). Gdańsk, Arche.

Pawlak K. (1994). Więziennictwo polskie w latach 1918-1939 (.Polish penitentiary system in the years 1918-1939). Kalisz. Centralny Ośrodek Szkolenia Służby Więziennej.

Przeglad Więziennictwa Polskiego (Review of the Polish Prisonership), (1927) no. 10-11.

Przeglad Więziennictwa Polskiego (Review of the Polish Prisonership), (1927) no. 4.

Przeglad Więziennictwa Polskiego (Review of the Polish Prisonership), (1927) no. 6.

Przeglad Więziennictwa Polskiego (Review of the Polish Prisonership), (1927) no. 9.

Przeglad Więziennictwa Polskiego (Review of the Polish Prisonership), (1928) no. 4.

Przegląd Więziennictwa Polskiego (Review of the Polish Prisonership), (1929) no. 3.

Przeglad Więziennictwa Polskiego (Review of the Polish Prisonership), (1931) no. 10.

Przegląd Więziennictwa Polskiego (Review of the Polish Prisonership), (1931) no. 11.

Przegląd Więziennictwa Polskiego (Review of the Polish Prisonership), (1932) no. 5.

Przeglad Więziennictwa Polskiego (Review of the Polish Prisonership), (1936) no. 1.

Przeniosło M. (2000). "Więzienie na Świętym Krzyżu w latach 1918-1939 (Prison on the Holy Cross in 1918-1939)," [in:] Klasztor na Świętym Krzyżu w polskiej kulturze narodowej (Holy Cross in Polish national culture), Gryz R., Olszewski D. (eds.), Kielce, Kieleckie Towarzystwo Naukowe.

Urban R., (2016), “Znaczenie wychowania fizycznego w polskim systemie penitencjarnym w dwudziestoleciu międzywojennym (The importance of physical education in the Polish penitentiary system in the interwar period," Prace Naukowe Akademii im Jana Dlugosza w Częstochowie, no. 2.

Bartosz KUŁAN (born on 11 March 1988) doctor of humanities, assistant professor at the Institute of Social Foundations of Penitentiary Science at the Higher School of Criminology and Penitentiary Science in Warsaw, graduate of history and law studies. In 2017, he was granted his doctoral degree at the Institute of History of the Jan Kochanowski University in Kielce. His first published book on the riot in the Święty Krzyż prison won a honourable mention in the competition for the best historical debut of the year. His papers and publications deal with the history of the penitentiary system and crime in interwar Poland.

ORCID ID: 0000-0002-5973-1188

This work is licensed under the Creative Commons Attribution International License (CC BY). http://creativecommons.org/licenses/by/4.0/ 